\title{
Bacterial Synthesis of Ternary CdSAg Quantum Dots through Cation Exchange: Tuning the Composition and Properties of Biological Nanoparticles for Bioimaging and Photovoltaic Applications
}

\author{
Nicolás Órdenes-Aenishanslins ${ }^{1}$, Giovanna Anziani-Ostuni ${ }^{1}$, Juan Pablo Monrás ${ }^{1,2}$, \\ Alejandra Tello ${ }^{3}$, Denisse Bravo ${ }^{4}$, Daniela Toro-Ascuy ${ }^{5}{ }^{(0)}$, Ricardo Soto-Rifo ${ }^{5}$, \\ Paras N. Prasad ${ }^{2, *}$ and José Manuel Pérez-Donoso ${ }^{1, * \mathbb{D}}$ \\ 1 BioNanotechnology and Microbiology Lab, Center for Bioinformatics and Integrative Biology (CBIB), \\ Facultad de Ciencias de la Vida, Universidad Andrés Bello, Av. República \#330, Santiago 8370186, Chile; \\ nicolas.ordenes@gmail.com (N.Ó.-A.); giovi.anziani@gmail.com (G.A.-O.); jpmonras@gmail.com (J.P.M.) \\ 2 Institute for Lasers, Photonics and Biophotonics, University at Buffalo, Buffalo, NY 14260, USA \\ 3 Laboratorio de Nanotecnología, Recursos Naturales y Sistemas Complejos, Facultad de Ciencias Naturales, \\ Departamento de Química y Biología, Universidad de Atacama, Copayapu 485, Copiapó 1531772, Chile; \\ atellozamorano@gmail.com \\ 4 Laboratorio de Microbiología Oral, Facultad de Odontología, Universidad de Chile, Sergio Livingstone \\ Pohlhammer \# 943, Santiago 8380492, Chile; denisseb@gmail.com \\ 5 Molecular and Cellular Virology Laboratory, Virology Program, Institute of Biomedical Sciences, Faculty of \\ Medicine, Universidad of Chile, Independencia, Santiago 834100, Chile; \\ daniela.toroascuy@gmail.com (D.T.-A.); rsotorifo@uchile.cl (R.S.-R.) \\ * $\quad$ Correspondence: pnprasad@buffalo.edu (P.N.P.); jose.perez@unab.cl (J.M.P.-D.)
}

Received: 7 February 2020; Accepted: 24 March 2020; Published: 27 April 2020

Abstract: In this study, we introduce a biological method for the production of ternary Quantum Dots (QDs): complex nanostructures with tunable optical and structural properties that utilizes post-synthesis modifications through cation exchange. This versatile in-situ cation exchange method being reported for the first time shows great potential for extending the scope of microbial synthesis. By using this bacterial-based method, we easily synthesize and purify CdS, CdSAg, and $\mathrm{Ag}_{2} \mathrm{~S}$ nanocrystals of a size below $15 \mathrm{~nm}$ and with variable morphologies that exhibit fluorescence emissions covering a broad spectral range (from 400 to $800 \mathrm{~nm}$ ). Energy-dispersive X-ray spectroscopy (EDS) results indicate the partial replacement of $\mathrm{Cd}^{2+}$ by $\mathrm{Ag}^{+}$when $\mathrm{AgNO}_{3}$ concentration is increased. This replacement produces CdSAg ternary QDs hetero-structures with high stability, fluorescence in the NIR-I (700 - $800 \mathrm{~nm})$, and $36.13 \%$ quantum yield. Furthermore, this reaction can be extended for the production of soluble $\mathrm{Ag}_{2} \mathrm{~S}$ nanoparticles (NPs) without any traces of $\mathrm{Cd}$. QDs biosynthesized through this cation exchange process display very low toxicity when tested in bacterial or human cell lines. Biosynthesized ternary hetero-structures were used as red fluorescent dyes to label HeLa cells in confocal microscopy studies, which validates its use in bioimaging applications in the near infrared region. In addition, the application of biologically-produced cadmium NPs in solar cells is reported for the first time. The three biosynthesized QDs were successfully used as photosensitizers, where the CdSAg QDs show the best photovoltaic parameters. Altogether, obtained results validate the use of bacterial cells for the controlled production of nanomaterials with properties that allow their application in diverse technologies. We developed a simple biological process for obtaining tunable Quantum Dots (QDs) with different metal compositions through a cation exchange process. Nanoparticles (NPs) are produced in the extracellular space of bacterial cells exposed to cysteine and $\mathrm{CdCl}_{2}$ in a reaction that depends on $\mathrm{S}^{2-}$ generation mediated by cysteine desulfhydrase enzymes and uses cellular biomolecules to stabilize the nanoparticle. Using this extracellular approach, water-soluble fluorescent $\mathrm{CdS}, \mathrm{CdSAg}$, and $\mathrm{Ag}_{2} \mathrm{~S}$ Quantum Dots with a tunable emission ranging 
from 400 to $800 \mathrm{~nm}$ were generated. This is the first study reporting the use of microorganisms to produce tunable ternary QDs and the first time that a cation exchange process mediated by cells is described. Obtained results validate the use of biological synthesis to produce NPs with new characteristics and opens a completely new research field related to the use of microorganisms to synthesize complex NPs that are difficult to obtain with regular chemical methods.

Keywords: ionic exchange; tunable nanoparticles; aqueous synthesis; nanoparticle biosynthesis

\section{Introduction}

Synthesis of nanoparticles using microorganisms (biosynthesis) represents a novel alternative to traditional chemical synthesis that allows economical production of biocompatible nanostructures with a tunable size and physical properties. During biosynthesis, different biomolecules interact with these in-situ produced nanoparticles (NPs) by modifying their surface and improving their stability as well as their biological function and cytotoxicity [1,2].

Even when the utilization of a variety of eukaryotic and prokaryotic organisms to generate different metal nanoparticles, like $\mathrm{Au}$ and $\mathrm{Ag}$, was reported [3-6], little is known about the process of microbiological synthesis of semiconductor nanoparticles such as Quantum Dots (QDs). QDs are an important type of inorganic nanoparticles for numerous technological applications [7].

QDs biosynthesis is a more complex process than biological synthesis of metal nanoparticles (e.g., $\mathrm{Cu}^{0}, \mathrm{Te}^{0}, \mathrm{Ag}^{0}$ ) because the formation of nanostructures with multiple compositions requires the interaction of elements in a certain oxidation state (e.g., $\mathrm{Cd}^{2+}, \mathrm{S}^{2-}, \mathrm{Te}^{2-}, \mathrm{Ag}^{+}$). In general, most protocols for CdS QDs biosynthesis in bacteria involve thiols and/or metal binding cysteine-rich molecules such as phytochelatins and metallothioneins [8,9]. Cellular thiols provide a source of $\mathrm{S}$ for $\mathrm{CdS}$ and also act as stabilizing agents coating the nanoparticle [10,11]. Some sulfate reducing bacteria (such as Desulfovibrio desulfuricans) or enterobacteria (such as Salmonella enterica serovar Typhimurium) can reduce sulfate or thiosulfate to produce $\mathrm{H}_{2} \mathrm{~S}[12,13]$. Our laboratory has previously reported that metabolically-produced $\mathrm{H}_{2} \mathrm{~S}$ is responsible for the formation of CdS and CdTe QDs at a low temperature [14,15]. Although E. coli does not have these systems, $\mathrm{H}_{2} \mathrm{~S}$ is generated in the presence of L-cysteine as a byproduct of cysteine desulfhydrase enzymatic activity [16]. In this sense, the use of L-cysteine as a $\mathrm{H}_{2} \mathrm{~S}$ precursor in $\mathrm{E}$. coli cells and the use of a purified cysteine desulfhydrase enzyme for the biological synthesis of CdS nanoparticles have been recently reported [17,18].

The number of publications describing the biosynthesis of Cd-based QDs has increased in recent years. However, the application of biosynthesis processes for a precise control of QDs properties, or the use of microorganisms to produce QDs with novel compositions have been scarcely reported. In this context, the importance of phosphorylated molecules to control the characteristics of Cd-based QDs synthesized by E. coli has been demonstrated [19]. In addition, in recent years, the few publications that have reported the use of biosynthesis to generate QDs with improved properties described an increased biocompatibility. Nevertheless, recently, our group published the use of extremophile acidophilic microorganisms to synthesize CdS QDs with high stability at acidic conditions [20] and the use of polyextremophile halophilic bacteria to produce QDs with increased stability under osmotic stress conditions [21]. This biosynthetic process is highly versatile and has been recently used for the controlled production of CdS/CdSe Core/Shell QDs. These Cd-based nanomaterials were specifically designed for photovoltaic applications and their use as "bio-sensitizers" in QDs-sensitized solar cells was reported for the first time [22]. Based on this and the inherent advantages of using microorganisms as nanocrystal bio-factories, we believe that the biosynthesis process constitutes a unique opportunity to generate nanoparticles with improved properties, such as ternary QDs, that could contribute to the development of new technologies and applications. 
Ternary Quantum Dots (QDs) such as HgCdTe, CdZnS, or CdSAg are vital for the manufacturing of new multifunctional materials and for obtaining a greater control of the optoelectronic properties of NPs [23-25]. The addition of metals such as $\mathrm{Mn}^{2+}, \mathrm{Zn}^{2+}$, and $\mathrm{Ag}^{2+}$, among others, is used to modify the properties of nanoparticles such as growth rate, photoluminescence, size, and crystal phase [26,27]. The variation in the composition of ternary QDs generates hetero-structures with desirable properties for biomedical applications, such as increased tissue penetration, less interference (auto-fluorescence), and reduced photochemical damage [28,29].

While methods for de novo synthesis of NPs have advanced considerably, post-synthesis modifications enabling the development of complex materials such as ternary QDs are scarce. Among these methods, cation exchange is a useful and versatile tool for controlling the composition and properties of synthesized NPs $[30,31]$. In this process, cations forming the nanocrystal (e.g., $\mathrm{Cd}^{2+}$ in $\mathrm{CdS}$ ) are replaced by those in solution (e.g., $\mathrm{Ag}^{+}$in $\mathrm{AgNO}_{3}$ solution), which allows the generation of complex hetero-structures through a delicate control of the NP composition [32]. Cation exchange is useful for the synthesis of complex nanostructures and, to date, no reports of biomimetic or biological methods to synthesize NPs involving cation exchange have been published.

In the present work, we describe a new biological synthesis method to obtain water dispersible fluorescent CdS, CdSAg, and $\mathrm{Ag}_{2} \mathrm{~S}$ nanoparticles using E. coli cells. Results indicate the partial replacement of $\mathrm{Cd}^{+2}$ by $\mathrm{Ag}^{+}$when biosynthesized CdS QDs are exposed to $\mathrm{AgNO}_{3}$ concentrations. This is a process that requires the presence of living cells and occurs through a cation exchange mechanism.

\section{Materials and Methods}

\subsection{Bacterial Strains and Stock Solutions}

The bacterial strain used in all experiments was Escherichia coli BW25113. All stock solutions were prepared in Type I Ultrapure water (Winkler, Santiago, Chile).

\subsection{Extracellular Biosynthesis of QDs}

E. coli was grown in an $\mathrm{LB}$ culture medium at $37^{\circ} \mathrm{C}$ under $180 \mathrm{rpm}$ agitation. After reaching an exponential phase $\left(\mathrm{OD}_{600} \sim 0.6\right)$, cells were washed twice with Borax-Citrate buffer $15 \mathrm{mM}$ (pH 9.4) and then suspended in buffer supplemented with $1.0 \mathrm{mM}$ cysteine and $100 \mu \mathrm{M} \mathrm{CdCl}_{2}$ (Sigma-Aldrich, St. Louis, MO, USA). Cultures were left in a $37^{\circ} \mathrm{C}$ shaker. Aliquots were obtained after different time intervals, centrifuged to discard bacterial cells $(15 \mathrm{~min}$ at $13.000 \times \mathrm{g})$, and the fluorescence of supernatants was evaluated.

For the biosynthesis of CdSAg and $\mathrm{Ag}_{2} \mathrm{~S}$ QDs, right after the addition of $\mathrm{CdCl}_{2}$ and cysteine, different concentrations of $\mathrm{AgNO}_{3}$ (Sigma-Aldrich, St. Louis, MO, USA) were added to the suspended cells. The $\mathrm{AgNO}_{3}$ concentrations used for the experiments were between 15 to $200 \mu \mathrm{M}$. Then, the cultures were centrifuged for $15 \mathrm{~min}$ at $13.000 \times g$ and the NPs were recovered from the supernatant.

\subsection{Evaluation of Cell Extracts to Produce QDs}

E. coli was grown in LB culture medium at $37^{\circ} \mathrm{C}$ with constant agitation $(180 \mathrm{rpm})$. After reaching an exponential phase $\left(\mathrm{OD}_{600} \sim 0.6\right)$, cells were washed twice with Borax-Citrate buffer $15 \mathrm{mM}$ (pH 9.4). After that, the cells were homogenized three times using glass beads and the FastPrep- $24^{\mathrm{TM}}$ Classic (MP Biomedicals, LLC, Irvine, USA) for $1 \mathrm{~min}$ at $4 \mathrm{~m} / \mathrm{s}$. Subsequently, the samples were centrifuged for $3 \mathrm{~min}$ at $27,670 \times \mathrm{g}$ and the synthesis of nanoparticles was evaluated in the conditions described above. Protein concentration of the lysate was determined by a Quick Start ${ }^{\mathrm{TM}}$ Bradford Protein Assay (Bio-Rad Inc., Hercules, CA, USA).

\subsection{Purification and Concentration of Extracellular Nanoparticles}

Culture supernatant containing the nanoparticles was filtered through 0.22- $\mu \mathrm{m}$ filters (Jet BioFiltration Co., Guangzhou, China) to eliminate the cells and other particles. Purification and 
concentration of the filtered NPs was obtained by ultracentrifugation with $3 \mathrm{kDa}$ Amicon ${ }^{\circledR}$ Ultra filters (Merck Millipore, Burlington, VT, USA) according to manufacturer's instructions.

\subsection{Characterization of the Nanoparticles}

\subsubsection{SEM and Elemental Analysis (EDS)}

Purified CdS, CdSAg, and $\mathrm{Ag}_{2} \mathrm{~S}$ NPs samples were coated with gold and then visualized by scanning electron microscopy at $20 \mathrm{kV}$ on a Hitachi SU70SEM FESEM. The elemental analysis of the biosynthesized NPs was made on the same equipment using an Energy-dispersive X-ray Spectrometer (EDS) detector.

\subsubsection{Spectroscopic Properties}

Absorbance and fluorescence spectra of purified nanoparticles produced by bacteria were measured by using a multiplate reader Synergy ${ }^{\mathrm{TM}} \mathrm{H} 1$ (BioTek Instrument Inc, Winooski, VT, USA). Emission spectra were obtained after excitation at $365 \mathrm{~nm}$ and recorded in the range of $400-800 \mathrm{~nm}$.

\subsubsection{Quantum Yield (QY)}

The following procedure of Quantum Yield (QY) determination was applied to purified CdS and CdSAg NPs solved in distilled water, and also for Nile blue in ethanol (QY $=0.27$ ) (Sigma-Aldrich, St. Louis, MO, USA). Different samples with absorbance values between 0.01 and 0.1 A.U. under excitation at $360 \mathrm{~nm}$ were prepared. Fluorescence spectra were recorded for obtaining the integrated fluorescence intensity (IFI). Then, IFI was plot versus the absorbance of NPs' solutions. Curves' slopes $(m)$ and refractive index of the solvent $(n)$ (water: 1.333, and ethanol: 1.335 ) were used to calculate NPs QY by considering Nile blue as reference $(R)$, using the following equation: $Q Y_{N P_{S}}=$ $Q Y_{R}\left[m_{N P S} / m_{R}\right]\left[n^{2}{ }_{N P S} / n^{2}{ }_{R}\right]^{-1}[19]$.

\subsubsection{X-ray Diffraction (XRD)}

XRD patterns were obtained using a Bruker D8 Advance model and Lynxeye detector. Cu-K $\alpha$ Radiation ( $30 \mathrm{~mA}, 40 \mathrm{KV}, \lambda=1.54 \AA$ ) had a scanning range of $10^{\circ}-80^{\circ}$ and step of $0.002^{\circ}$.

\subsubsection{High-Resolution Transmission Electron Microscopy (HR-TEM)}

High-resolution transmission electron microscopy (HR-TEM) measurements were made using a JEOL JEM 2010, operated at $200 \mathrm{kV}$. For these studies, a drop of the dispersed sample was left to dry out on a commercial coal formvar $\mathrm{Cu}$ TEM grid 300 mesh copper grid hole with a size of $63 \mu \mathrm{m}$. HRTEM images were processed and analyzed with Digital Micrograph 3.9.0 (Gatan Inc.) and the Gimp 2.4.0 software packages. A statistical study of HRTEM images was carried out in order to quantify the particle size by measuring the diameter of 150 particles for each sample. Counts were then plotted as frequency histograms and the mean particle size was calculated. Chemical characterization of the samples was performed by Energy-dispersive X-ray spectroscopy (EDS o EDX) and ED (electron diffraction).

\subsubsection{Fourier Transform Infrared Spectroscopy (FT-IR)}

Biosynthesized QDs were lyophilized and the obtained powder was mixed with $\mathrm{KBr}$ (Sigma-Aldrich, USA). Obtained KBr pellets were measured in a solid FT-IR spectrometer between 4000 and $400 \mathrm{~cm}^{-1}$, using a Spectrum Two FT-IR Spectrometer (PerkinElmer Inc., Waltham, MA, USA). 


\subsection{Toxicity of Biosynthesized Nanoparticles}

\subsubsection{MTS Cell Proliferation Assay}

To assess the cytotoxicity of NPs on eukaryotic cells, an MTS (3-(4,5- dimethylthiazol-2-il)5-(3-carboxymethoxyphenyl)-2-(4-sulfophenyl)-2H-tetrazolium) (Promega Co., Madison, WI, USA) assay was performed in AGS human gastric cancer cells. A total of 20,000 cells per well were incubated for $24 \mathrm{~h}$ at $37^{\circ} \mathrm{C}$ and $5 \% \mathrm{CO}_{2}$ to allow adherence of cells to the plate. After $24 \mathrm{~h}$, cells were treated with different concentrations and dilutions of NPs. Again, treated cells were incubated for $24 \mathrm{~h}$ at $37^{\circ} \mathrm{C}$ and $5 \% \mathrm{CO}_{2}$. Then, cells were washed with PBS (3 times) and treated with $100 \mathrm{~mL}$ of a mixture of phenazine methosulfate and MTS regarding the ratios indicated by the manufacturer (Promega Co., Madison, WI, USA). After $1 \mathrm{~h}$ of incubation, the absorbance at $490 \mathrm{~nm}$ was measured.

\subsubsection{Effect of Biosynthesized QDs on Bacterial Growth}

The effect of biosynthesized QDs on E. coli growth was evaluated following the protocol previously described [33]. Briefly, E. coli cultures $\left(\mathrm{OD}_{600} \sim 0.15\right)$ were incubated at $37{ }^{\circ} \mathrm{C}$ with agitation in the presence of QDs $(100,300$, and $500 \mu \mathrm{g} / \mathrm{mL})$ and turbidity was measured using a Unico 2800 UV-vis spectrophotometer.

\subsection{Fluorescence Microscopy}

HeLa cells were cultured in 12-well plates with covers glass at 100.000 cells/well and transfected with $25 \mu \mathrm{L}$ of polyethylenimine (PEI) (PolySciences Inc., Warrington, USA) at $300 \mathrm{mg} / \mathrm{L}$ and $50 \mu \mathrm{L}$ CdSAg at $10 \mathrm{mg} / \mathrm{mL}$. As treatment controls, only the PEI or only the CdSAg were used. At $24 \mathrm{~h}$ post transfection, cells were washed twice with $1 \times$ PBS and fixed for $10 \mathrm{~min}$ at room temperature with $4 \%$ paraformaldehyde (Sigma-Aldrich, St. Louis, MO, USA). Then, cells were washed three times with $1 \times$ PBS. Lastly, nuclei were labeled for $1 \mathrm{~min}$ with a $0.3 \mu \mathrm{g} / \mathrm{mL}$ solution of $4^{\prime}$, 6-diamino-2-phenylindole (DAPI) (Life Technologies Co., Carlsbad, CA, USA) in PBS, at room temperature, washed three times with $1 \times$ PBS, washed three times with water, and mounted with 1,4-diazabicyclo [2.2.2] octane (DABCO) (Merck Millipore, Burlington, VT, USA). Images were obtained with a TCS SP8 Confocal Microscope (Leica Microsystems, Wetzlar, Germany) and obtained images were processed using FIJI/ImageJ (NIH). Excitation was $555 \mathrm{~nm}$ and depletion was $660 \mathrm{~nm}$.

\subsection{Fabrication and Characterization of Quantum Dot Sensitized Solar Cells (QDSSC)}

QDSSCs were produced following the protocol previously described by our group [34] with some modifications. To fabricate the electrodes, $20 \times 20 \times 2 \mathrm{~mm}$ in size fluorine-doped tin oxide coated glass (FTO glass) TEC15 with a surface resistivity of $13[\Omega / \mathrm{sq}]$ and $85 \%$ transmittance was used (Sigma-Aldrich, St. Louis, MO, USA). Conductive glasses were cleaned by successive sonication in absolute ethanol and deionized water for approximately $10 \mathrm{~min}$ to remove organic contaminants. The anode was prepared using a suspension of titanium (IV) oxide nanoparticles $\left(\mathrm{TiO}_{2} \mathrm{Nano}\right.$ powder $\sim 21 \mathrm{~nm}$ particle size and anatase crystal structure, Sigma-Aldrich USA) that was deposited on the glass by spin-coating at $2000 \mathrm{rpm}$ for $10 \mathrm{~s}$. $\mathrm{TiO}_{2}$ film underwent a sintering process at $465{ }^{\circ} \mathrm{C}$ for $20 \mathrm{~min}$ and sensitization was performed by direct adsorption. The electrode active area $\left(1 \mathrm{~cm}^{2}\right)$ was treated once with $50 \mathrm{mg} / \mathrm{mL}$ NP solution and incubated in darkness. The cathode or counter electrode was prepared as previously described [34]. Then, the photoanode and the counter electrode were assembled by leaving a 127- $\mu \mathrm{m}$ space between them. Before sealing the cell, $7 \mu \mathrm{L}$ of electrolyte sulfide/polysulfide $\left(\mathrm{S}^{2-} / \mathrm{S}_{n}{ }^{2-}\right)$ solution was added $\left(\mathrm{Na}_{2} \mathrm{~S} 1.0 \mathrm{M}, \mathrm{S} 0.1 \mathrm{M}, \mathrm{NaOH} 0.1 \mathrm{M}\right.$, from Sigma-Aldrich, USA, in ultrapure water from Winkler Ltd.a., Chile). Characterization of solar cells was performed in triplicate for each NP using a solar simulator (A1 Solar LightLine, Sciencetech Inc., ON, Canada) and a current-voltage measurement system (IV Tester- 20W, Sciencetech Inc., ON, Canada). Measurements were performed under constant conditions of temperature and irradiance at a one sun intensity as the light source $\left(\sim 100 \mathrm{~mW} \cdot \mathrm{cm}^{-2}\right.$ and AM1.5). 


\section{Results}

\subsection{Biosynthesis of CdS QDs in E. coli}

An intrinsic property of QDs is the fluorescence emission when excited with UV light. Based on this, bacterial synthesis of QDs can be determined by detecting fluorescence emission in cell pellets and supernatants $[11,14]$. E. coli cells at an exponential growth phase were exposed to $\mathrm{Cd}^{+2}$ and cysteine, and the time-dependent shift in NPs growth was determined by measuring QDs-associated bacterial fluorescence in cell cultures exposed to UV light. Furthermore, different fluorescence emission colors were observed in culture supernatants (extracellularly) at different incubation times, which changed from green to yellow and then to red (Figure 1a). CdS nanoparticles obtained by extracellular biosynthesis also display different emission spectra depending on reaction time with emission profiles ranging from 500 to $700 \mathrm{~nm}$ (Figure 1b). This is a characteristic behavior of QDs associated with the increase of NPs' size [14,19].

a) Incubation time (min)

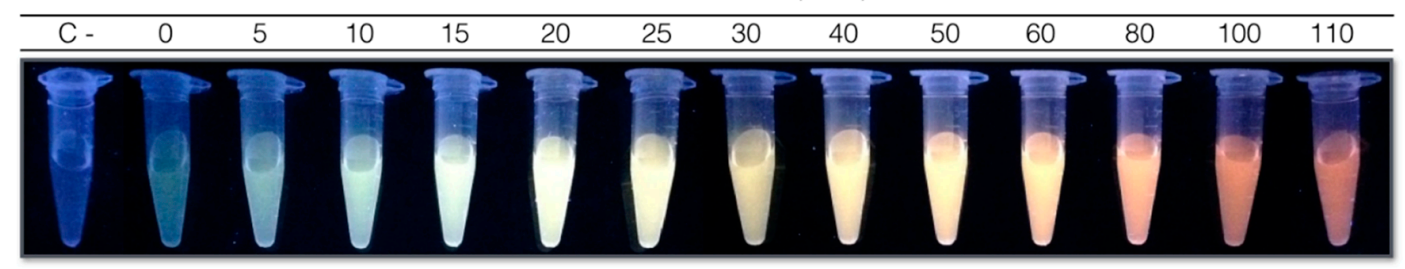

b)

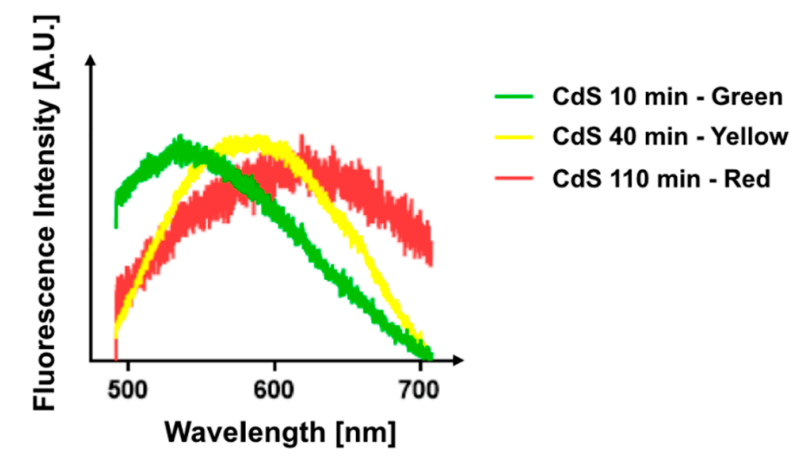

Figure 1. (a) Kinetics of extracellular biosynthesis of CdS Quantum Dots (QDs). Ultra Violet-exposed supernatants of bacterial cultures at different incubation times with cadmium and cysteine $\left(\lambda_{\text {exc }}=365 \mathrm{~nm}\right)$. (b) Fluorescence emission spectra of the three most representative fractions obtained during QDs biosynthesis $\left(\lambda_{\mathrm{exc}}=405 \mathrm{~nm}\right)$.

\subsection{Biosynthesis of Ternary QDs in E. coli}

Some chemical methods to synthesize CdS QDs involve the addition of metals as dopants to modify the properties of NPs and generate complex nanostructures $[26,27,35]$. To evaluate the effect of $\mathrm{Ag}^{2+}$ on CdS nanoparticles, we used $\mathrm{AgNO}_{3}$ as a silver source since there is evidence for this metal to help in cation exchange interactions and because CdS/Ag structures display unique optical properties $[32,36,37]$.

When increasing $\mathrm{Ag}^{+}$concentrations in the extracellular biosynthesis reaction $\left(\mathrm{AgNO}_{3} 15\right.$ to $40 \mu \mathrm{M}$ ), the spectroscopic properties of CdS-QDs present in bacterial supernatants changed (Figure 2a). Silver-treated solutions (none-exposed to UV light) display significant changes in color, changing from uncolored to a red color after exposure to $\mathrm{AgNO}_{3} 40 \mu \mathrm{M}$, or to a dark gray when $\mathrm{AgNO}_{3} 200 \mu \mathrm{M}$ was used in the reaction (Figure $2 \mathrm{~b}$ ). The emission of the nanoparticles produced in the presence of $\mathrm{Ag}^{+}$is red shifted with emissions between 650 and $800 \mathrm{~nm}$ as compared to CdS ranging from 500 to 
$700 \mathrm{~nm}$ (Figure 2c). This shift in the fluorescence spectra forms a static point that does not change in all concentrations of $\mathrm{AgNO}_{3}$ tested, called an isosbestic point (IP). The existence of an IP indicates that the reaction involves the conversion of one species into a unique other species, or that an equilibrium between only two species is reached. It certainly shows that the stoichiometry of the reaction remains unchanged during the chemical reaction and that no secondary reactions occur during the considered time range.

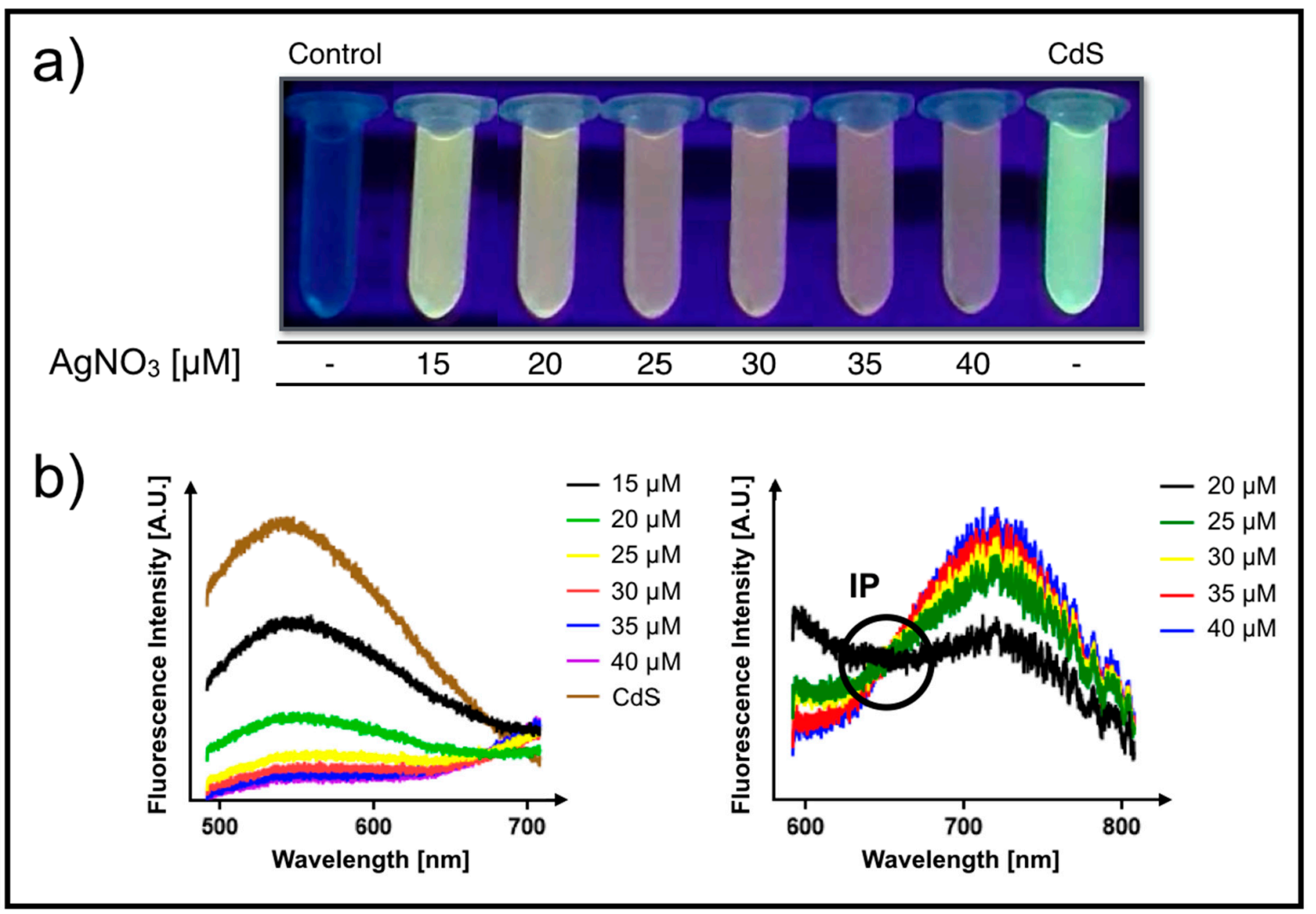

Figure 2. Biosynthesis of CdS Quantum Dots (QDs) in the presence of different $\mathrm{AgNO}_{3}$ concentrations (15 to $40 \mu \mathrm{M})$. Negative control condition contains $\mathrm{CdCl}_{2}(100 \mu \mathrm{M})$ in the absence of cysteine (no fluorescence). The positive control (CdS) was conducted without the addition of $\mathrm{AgNO}_{3}$. (a) Biosynthesis solutions obtained in the presence of different $\mathrm{AgNO}_{3}$ concentrations exposed and not exposed to UV. Concentrations of reagents used in each reaction are indicated. $(\mathbf{b}, \mathbf{c})$ Fluorescence spectra of samples containing $\mathrm{AgNO}_{3}$ at different concentrations. The isosbestic point (IP) is also shown.

\subsection{Characterization of Biosynthesized Ternary QDs}

NPs biosynthesized under three selected conditions $(0,40$, and $200 \mu \mathrm{MAgNO}$ ) were purified and characterized. As the first characterization, XRD analyses were performed for the three purified QDs. As shown in Figure 3, wide diffraction peaks were observed in all samples. According to the Scherrer equation and assuming homogeneous tension, these peaks are consistent with the characteristic pattern of nanoparticles or small crystallites (Figure 3) [38]. In the case of CdS-NPs, a single diffraction plane at (200), corresponding to the Hawleyite mineral phase as derived from the CPDS pattern, was observed (Figure 3, CdS) [39]. NPs produced in the presence of $200 \mu \mathrm{M} \mathrm{AgNO} 3$ (Figure 3, $\mathrm{Ag}_{2} \mathrm{~S}$ ) shows a single diffraction peak in the crystallographic plane (111), corresponding to the CPDS pattern of the Argentite cubic phase, $\mathrm{Ag}_{2} \mathrm{~S}$ [40]. These results indicate that $\mathrm{CdS}$ and $\mathrm{Ag}_{2} \mathrm{~S}$ NPs have a preferential orientation for crystalline growth. When $40 \mu \mathrm{M} \mathrm{AgNO}_{3}$ was incorporated in the biosynthesis solution, more than one diffraction peak was observed, which suggests the formation of a ternary structure (Figure 3, CdSAg). Since increased noise from the diffraction peak between 20 and $35^{\circ}$ indicate more than one signal or fusion of multiple diffraction peaks, deconvolution, and Lorentzian curves adjustment were performed. 
From these adjustments, it is assumed that the diffraction peak for the first Lorentzian correspond to a crystalline plane (111), while the second one corresponds to a CdS crystalline plane (200), which is congruent with the Hawleyite phase of the CPDS pattern. For the third Lorentzian, the diffraction peak adjustment for the crystalline plane (111) of $\mathrm{Ag}_{2} \mathrm{~S}$ is congruent with the Argentite phase CPDS pattern. Additionally, diffraction peaks at (220) and (113) were observed, which correspond to the CdS Hawleyite phase CPDS pattern (Figure 3, CdS).

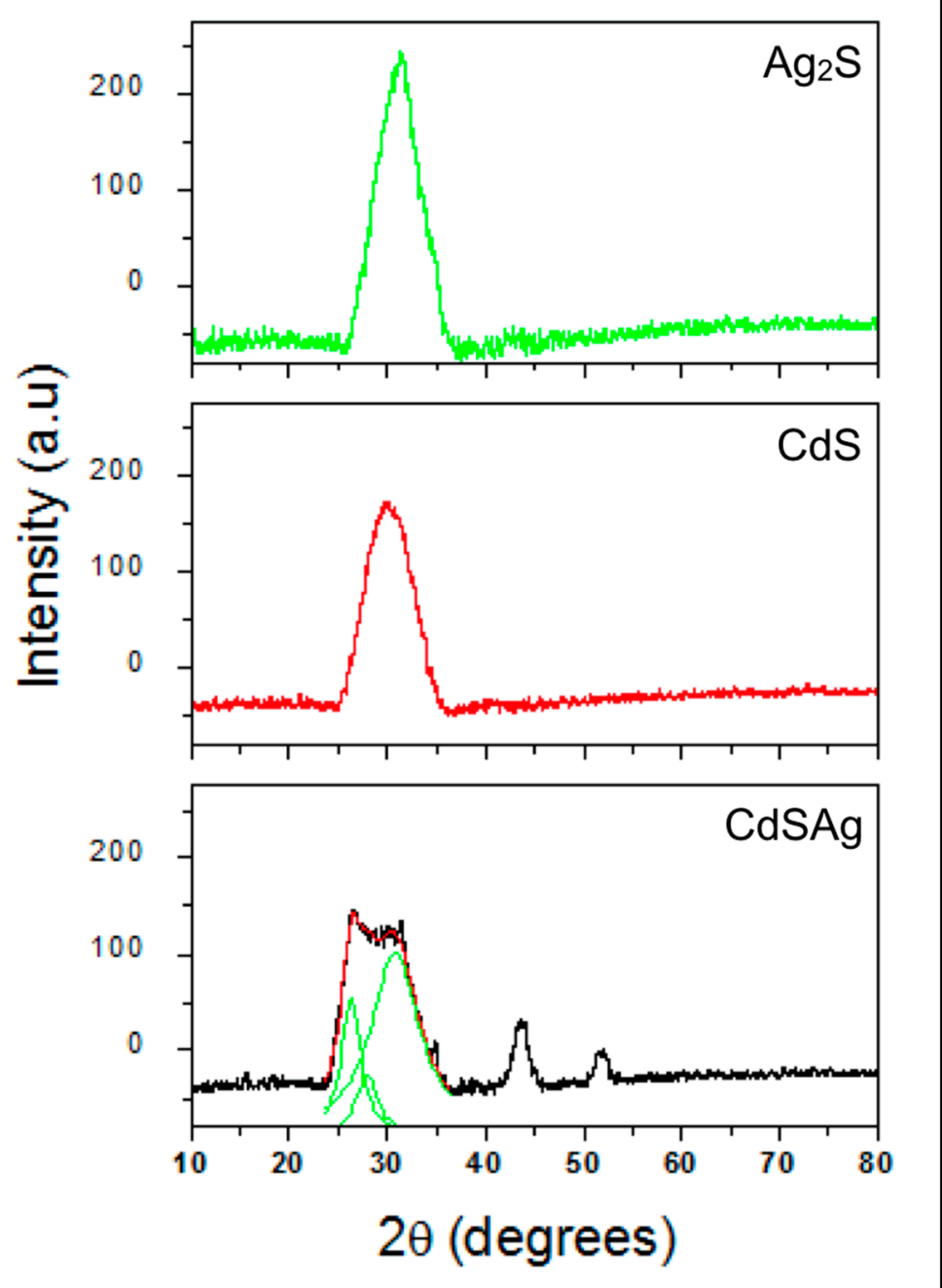

Figure 3. X-ray diffractograms of nanoparticles biosynthesized by E. coli, for $\mathrm{Ag}_{2} \mathrm{~S}, \mathrm{CdS}$ and CdSAg purified nanoparticles.

Biosynthesized NPs were then analyzed by High-Resolution Transmission Electron Microscopy (HR-TEM). As shown in Figure 4, regular polyhedral nanometric structures were observed for CdS and CdSAg NPs (Figure 4a,b). The NPs' average diameter was determined from frequency histograms, corresponding to $5.49 \mathrm{~nm}$ for CdS NPs and $7.20 \mathrm{~nm}$ for CdSAg NPs (Figure 4a,b). 


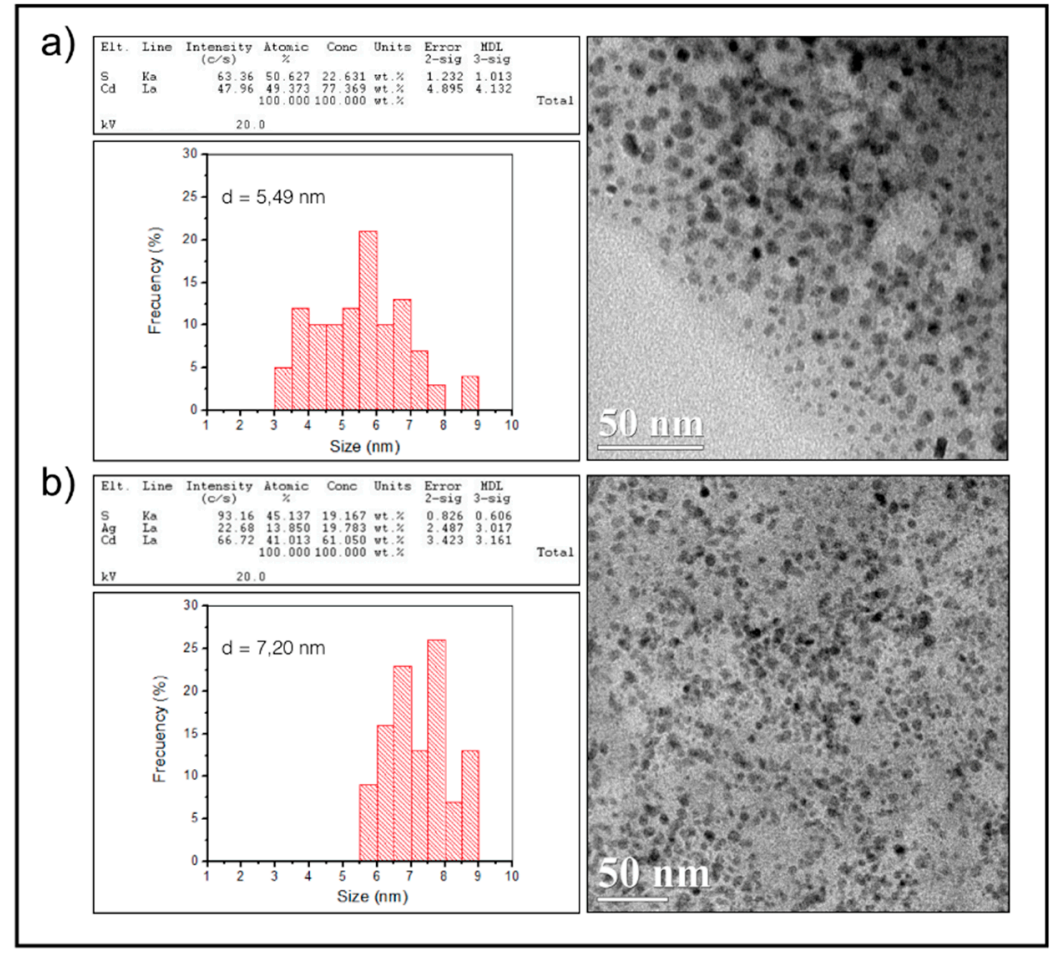

Figure 4. EDS, HR-TEM, and frequency histograms of biosynthesized CdS (a) and CdSAg (b) nanoparticles.

The energy-dispersive X-ray spectroscopy (EDS) analysis for the CdS NPs indicated that Cd and S elements are present with an atomic proportion of 50\% and 49\%, respectively (Figure 4a). Additionally, the EDS analysis of the ternary NPs produced in the presence of $40 \mu \mathrm{M} \mathrm{AgNO}$ indicated the presence of $\mathrm{Cd}, \mathrm{S}$, and $\mathrm{Ag}$ elements with an atomic proportion of $41.013 \%, 45.137 \%$, and $13.850 \%$, respectively (Figure 4b).

Quantum yield (QY) values of fluorescent nanoparticles (0 and $40 \mu \mathrm{M} \mathrm{AgNO} 3$ ) were determined. The obtained results indicated QYs of $20.3 \%$ for CdS and 36.13\% for CdSAg QDs. Regarding ternary QDs biosynthesis, this is the maximum quantum yield reported for biologically produced nanostructures, which is a condition that reinforces the importance and novelty of this cell-based synthesis method, particularly considering their potential applications.

Most biologically produced nanomaterials display an external layer constituted by a variety of biological molecules that could affect their properties. To evaluate if the different Ag concentrations used for the biosynthesis of ternary QDs affects the organic components present in biosynthesized NPs, an FT-IR analysis was performed. Identical FT-IR spectra were determined for CdS, CdSAg, and $\mathrm{Ag}_{2} \mathrm{~S}$ nanoparticles (Figure S1). In all of them, the presence of signatures from the $\mathrm{O}-\mathrm{H}$ stretch $\left(3000-3700 \mathrm{~cm}^{-1}\right)$, aromatic $C=C\left(1700 \mathrm{~cm}^{-1}\right), C=\mathrm{O}\left(1500-1650 \mathrm{~cm}^{-1}\right), \mathrm{N}-\mathrm{H}$ bend $\left(1250-1450 \mathrm{~cm}^{-1}\right)$, and aliphatic amines (950-1100 $\left.\mathrm{cm}^{-1}\right)$ molecules were determined (Figure S1). All these signals can be attributed to the presence of biomolecules produced by E. coli and bound to the nanoparticles (i.e., proteins or peptides, coenzymes). These biomolecules can provide support for the nucleation of the nanoparticles, and/or be involved in the biosynthesis process acting as stabilizing and capping agents $[11,41,42]$.

Since one of the major problems that affect QDs' applications is their poor biocompatibility, we decided to evaluate the toxicity of NPs biosynthesized by our method. No effect of biosynthesized QDs on the growth of Escherichia coli was determined in cultures exposed to $100-500 \mu \mathrm{g} / \mathrm{mL}$ NPs concentrations (Figure S2). Despite chemical differences in the nanocrystal core, no significant differences on bacterial toxicity were observed between $\mathrm{CdS}, \mathrm{CdSAg}$, and $\mathrm{Ag}_{2} \mathrm{~S}$ NPs (Figure S2). This result is most likely a consequence of the similar capping composition present in the different NPs. 
In terms of eukaryotic cells, the biocompatibility of CdSAg was tested in human gastric cells (AGS). No toxicity was observed up to $50 \mu \mathrm{g} / \mathrm{mL}$ of NPs (Figure S3). However, a significant effect on viability was observed when AGS cells were exposed to $100 \mu \mathrm{g} / \mathrm{mL}$ of CdSAg NPs.

The unique conditions and characteristics of the biosynthetic process, and the properties determined in the as-produced nanomaterials, suggest that the formation of CdSAg hetero-structures is a consequence of a cation exchange reaction between $\mathrm{Cd}^{2+}$ and $\mathrm{Ag}^{+}$in the $\mathrm{CdS}$ ionic crystal [25,32]. In Figure 5b,c, HR-TEM image magnifications show the presence of electron dense regions in CdSAg NPs. If a cation exchange reaction occurs, an increase in the amount of $\mathrm{Ag}^{+}$would tend to exchange all the $\mathrm{Cd}^{2+}$ from the NPs, eventually forming $\mathrm{Ag}_{2} \mathrm{~S}$. As presented in the scheme in Figure $5 \mathrm{a}$, biological nanoparticles are obtained in three consecutive steps. First, nanometer sized CdS crystals are formed. These NPs present high fluorescence emission in the visible range. Then, as $\mathrm{Ag}^{+}$ions are added to the reaction, an intermediary structure between $\mathrm{CdS}$ and $\mathrm{Ag}_{2} \mathrm{~S}$ is produced. Lastly, the addition of a higher $\mathrm{AgNO}_{3}$ concentration pushes the reaction toward the formation of $\mathrm{Ag}_{2} \mathrm{~S} N P s$.

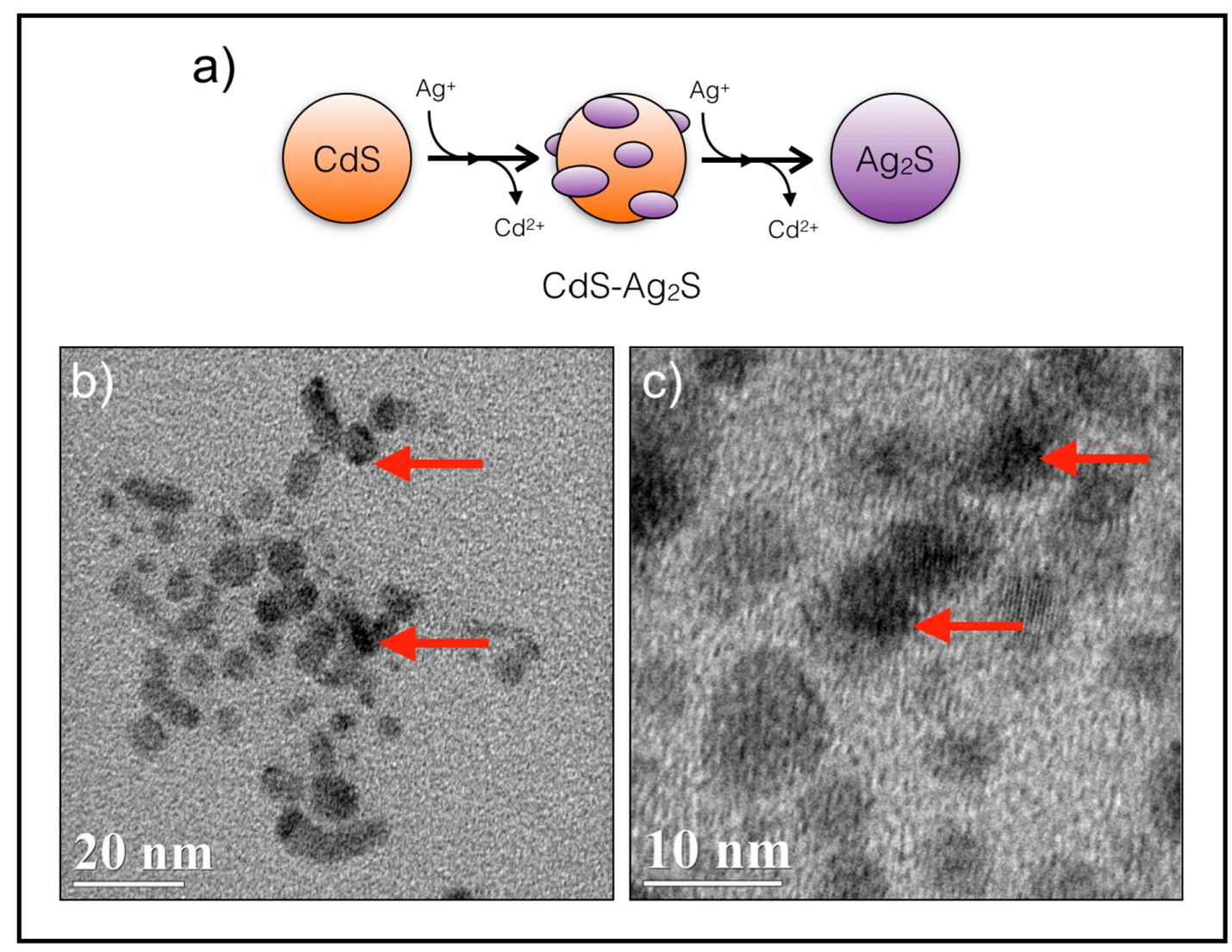

Figure 5. HR-TEM analysis of CdSAg biosynthesized nanoparticles. (a) Scheme of the formation of binary (CdS, $\mathrm{Ag}_{2} \mathrm{~S}$ ) and ternary (CdSAg) quantum dots by cation exchange. (b) and (c) Purified CdSAg NPs. Arrows indicate electrodense zones present in the ternary nanostructure.

\subsection{Ternary QDs Biosynthesis Requires Live E. coli Cells to Occur}

One of the most interesting aspects of this synthesis process is that the formation of crystalline heterostructures is conditioned to the presence of living E. coli cells (no fluorescence was observed in the presence of dead cells, not shown). To test if the cation exchange reaction can occur in the presence of cellular extracts, E. coli cell lysates were exposed to biosynthesis conditions ( $\mathrm{Cd}^{2+}$ and cysteine). As shown in Figure 6, fluorescence was observed when both cell lysates or living cells were exposed to biosynthesis conditions, indicating that both conditions produce QDs and render effective CdS nanocrystal seeds. As expected, when $\mathrm{AgNO}_{3}(40 \mu \mathrm{M})$ was added to the solution containing CdS QDs in the presence of bacterial cells, a red shift in fluorescence associated with ternary QDs production 
was observed. When $200 \mu \mathrm{M}$ of $\mathrm{AgNO}_{3}$ was added, no fluorescence was determined (as expected for $\mathrm{Ag}_{2} \mathrm{~S}$ NPs that are not fluorescent when exposed to UV light). On the other hand, when $\mathrm{AgNO}_{3}$ was incorporated to CdS QDs in the presence of cell lysates, no fluorescence was observed (Figure 6). This result indicates that living cells are required for the cation exchange process to occur in a reaction that likely involves active metabolic processes, a constant production of sulfide, and/or the generation or presence in its active form of different biomolecules (reduced thiols or proteins) among others.

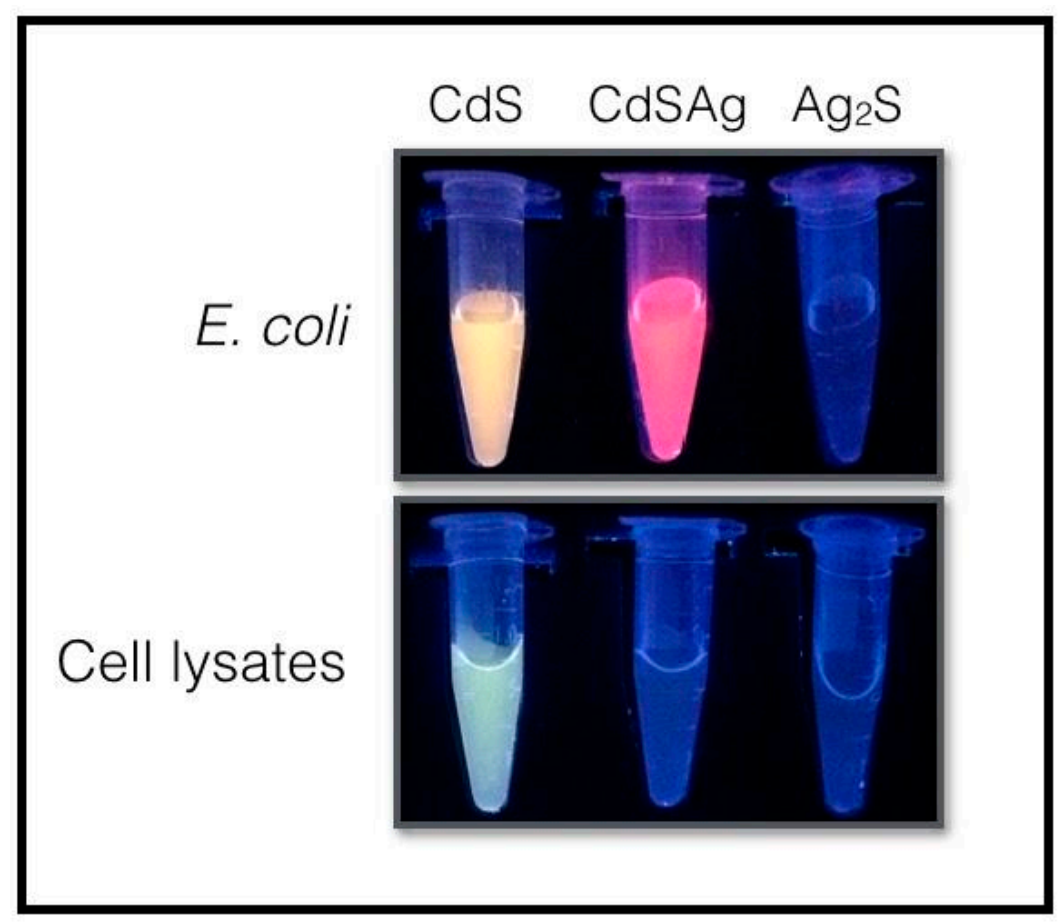

Figure 6. The synthesis of ternary cadmium/silver sulfide Quantum Dots requires living E. coli cells to occur. QDs synthesis reactions were performed in the presence of $E$. coli cells or cell lysates using the described CdS biosynthesis conditions ( $\mathrm{Cd}^{2+}$ and cysteine). $\mathrm{AgNO}_{3} 40$ or $200 \mu \mathrm{M}$ was used to produce CdSAg or $\mathrm{Ag}_{2} \mathrm{~S}$ NPs, respectively. Fluorescence was evaluated by exposing the tubes to ultraviolet (UV) light $\left(\lambda_{\text {exc }}=365 \mathrm{~nm}\right)$.

\subsection{Use of Ternary NPs in Bioimaging Applications}

As described above, ternary NPs produced by our biological cation exchange method display high biocompatibility and excellent spectroscopic properties such as high Quantum Yield and near-IR emission. These characteristics are highly desired when using fluorescent molecules to visualize biological samples (bioimaging applications). Ternary QDs were used to label HeLa cells that were co-labeled with DAPI (Figure 7). Based on previous results using biological and biomimetic Cd-QDs for labeling cells, the use of polyethylenimine (PEI) as a transfection agent is strongly suggested [43]. Additionally, in the absence of PEI, a small amount of red fluorescent cells was observed. When the transfection agent was incorporated, a high level of red labeling occurs all over the cytoplasm of HeLa cells, which validates the use of these biological QDs in bioimaging applications. 


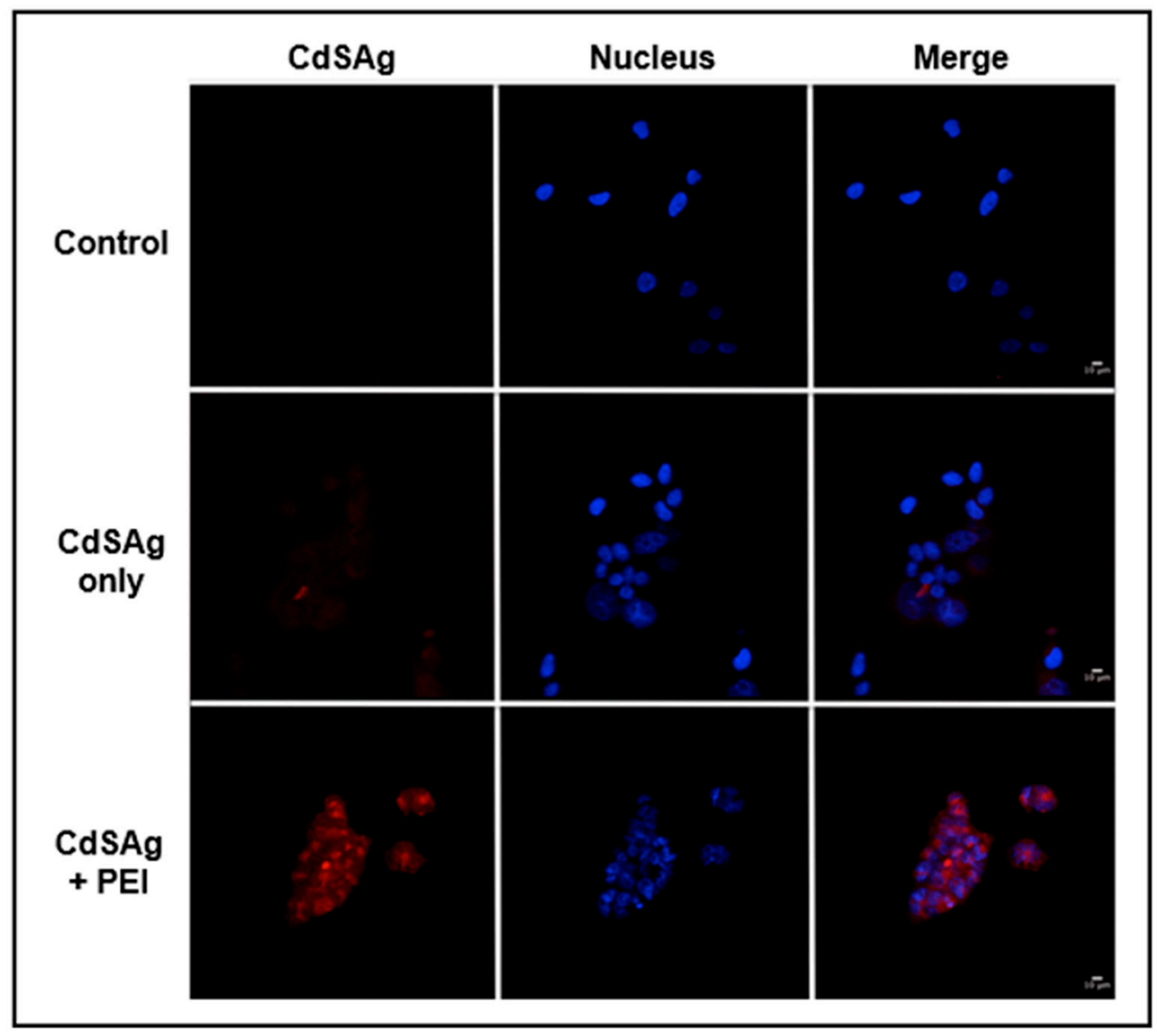

Figure 7. Use of biosynthesized CdSAg Quantum dots for labeling HeLa cells. HeLa cells were transfected with PEI and CdSAg QDs. Controls cells were treated only with PEI or CdSAg. Nuclei were labeled with DAPI. Images were obtained with a TCS SP8 Confocal Microscope and images were processed using FIJI/ImageJ (NIH).

\subsection{Use of Biosynthesized NPs as Sensitizers in Quantum Dot Sensitized Solar Cells (QDSSCs)}

Based on the optoelectronic properties and QY values of the biosynthesized nanoparticles, we decided to evaluate the function of biologically synthesized Cd-based QDs in Quantum Dot Sensitized Solar Cells (QDSSCs). In this solar cell, a film of $\mathrm{TiO}_{2}$ nanoparticles deposited on a conductive glass is sensitized with QDs forming the photoanode, while the cathode or counter electrode is platinum on glass. Obtained photovoltaic parameters of solar cells sensitized with each of the QDs biosynthesized through the cation exchange process are summarized in Table 1 (IV curves are shown in Supplementary Figure S4).

Table 1. Photovoltaic parameters of quantum dot sensitized solar cells constructed with biological Quantum Dots (QDs).

\begin{tabular}{ccccc}
\hline $\begin{array}{c}\text { Photoanode } \\
\text { Structure } \\
\text { (Sensitizer) }\end{array}$ & $\begin{array}{c}\text { Short Circuit } \\
\text { Current } \\
\mathbf{I}_{\mathbf{s c}}\left[\mathbf{m A} / \mathbf{c m}^{2}\right]\end{array}$ & $\begin{array}{c}\text { Open Circuit } \\
\text { Voltage } \\
\mathbf{V}_{\mathbf{~ o c}}[\mathbf{m V} \mathbf{m}\end{array}$ & $\begin{array}{c}\text { Fill Factor } \\
\text { FF [\%] }\end{array}$ & $\begin{array}{c}\text { Efficiency } \\
\mathbf{\eta}[\%]\end{array}$ \\
\hline $\mathrm{CdS}$ & $0.0238 \pm 0.00459$ & 155 & 65.5 & 0.00271 \\
\hline $\mathrm{CdSAg}$ & $0.1690 \pm 0.02940$ & 279 & 47.2 & 0.0222 \\
\hline $\mathrm{Ag}_{2} \mathrm{~S}$ & $0.0448 \pm 0.00187$ & 209 & 59.1 & 0.00547 \\
\hline
\end{tabular}

Characterization of solar cells was performed in triplicate for each nanoparticle. Average values \pm SE are shown. 
The solar cells sensitized with ternary QDs showed the highest values compared to those cells sensitized with CdS or $\mathrm{Ag}_{2} \mathrm{~S}$. The biosynthesized hetero-structure generated a $\mathrm{V}_{\mathrm{OC}}$ of $279 \mathrm{mV}, \mathrm{I}_{\mathrm{SC}}$ of $0.169 \mathrm{~mA} \mathrm{~cm}^{-2}$, and efficiency of $0.0222 \%$. As expected, the efficiency of the solar cell produced with ternary QDs was four times higher than the solar cell sensitized with $\mathrm{Ag}_{2} \mathrm{~S}$ NPs and eight times higher than the one sensitized with CdS QDs.

Obtained photovoltaic parameters validate the use of bacterially-produced QDs in QDSSCs and represent an interesting projection of the present work.

\section{Discussion}

In recent decades, the production of nanomaterials has been a topic of increasing interest because of their multiple technological applications. As a consequence, legal regulations for the production, application, and safety of nanomaterials have been continuously evolving and the industrial interest has oriented to the use of eco-friendly and sustainable production methods. In this context, the use of biological methods to synthesize nanomaterials has become an interesting alternative.

In general, synthesis of nanostructures using microorganisms as reaction mediators is an eco-friendly alternative to classical chemical methods. Faster synthesis times, lower production costs, and the possibility to include new metals that allow post-synthesis modifications are some benefits of choosing this method [1,2]. However, several improvements in terms of reproducibility, versatility, and scalability of biosynthesis procedures are still required. To date, the potential of biological methods for controlling the properties and stability of NPs has been scarcely studied. Recent studies have reported the use of different microorganisms as bio-factories to produce nanoparticles with novel properties [42,44]. Examples of this are extremophile acidophilic bacterium that produces QDs resistant to acidic conditions, salt stable QDs produced by halophilic microorganisms, low temperature biosynthesis using psychrotolerant Antarctic bacteria, the biosynthesis of QDs with increased biocompatibility by yeasts, and the use of bacteria for the production of core/shell QDs for photovoltaic applications $[15,20-22,44]$. In this context, the biosynthesis of complex nanomaterials, such as binary and ternary quantum dots, or the biological production of NPs with novel and controllable properties is a scarcely explored challenge.

This work is the first report of a biological method for obtaining extracellular ternary quantum dots using bacterial cells. The described methodology produces crystalline nanostructures with tunable optical properties and offers the option of post-synthesis modifications through a cation exchange process. The extracellular QDs produced by E. coli cells remain in the supernatant fraction and their emission is tunable in the visible and near IR range. The biosynthesis method involves the addition of cysteine into a bacterial culture, which promotes the generation of $\mathrm{H}_{2} \mathrm{~S}$ and the extracellular production of metal-sulfur nanoparticles $[14,15,17]$. The process takes advantage of bacterial enzymatic activities that release great amounts of $\mathrm{H}_{2} \mathrm{~S}$ in the presence of cysteine. This sulfur volatile compound diffuses through the bacterial membrane and reacts with intracellular cadmium as well as with metal ions outside the cell to form CdS QDs in the extracellular domain after $30 \mathrm{~min}[15,17]$. The Borax-Citrate buffer used in this method has been previously reported for the biosynthesis of CdS nanoparticles [22]. This reaction media allows the deprotonation of the $\mathrm{H}_{2} \mathrm{~S}$ produced by the bacteria, which allows the interaction of $\mathrm{S}^{2-}$ with $\mathrm{Cd}^{2+}$ to produce the crystal [22].

In terms of the biological process involved in ternary QDs biosynthesis, we have shown that E. coli is able to synthesize CdS, CdSAg, and $\mathrm{Ag}_{2} \mathrm{~S}$ NPs extracellularly when treated with $\mathrm{CdCl}_{2}$ and different concentrations of $\mathrm{AgNO}_{3}$. E. coli cells exposed to biosynthesis conditions metabolically produce $\mathrm{S}^{2-}$ and all the substrates required for nanocrystals biosynthesis including stabilizing agents such as cellular thiols, proteins, or peptides [45]. Even though CdS biosynthesis is observed with cell lysates, it is interesting that the presence of living cells is mandatory for the generation of CdSAg and $\mathrm{Ag}_{2} \mathrm{~S}$ NPs through cation exchange reactions (Figure 6). The interaction of bacterial biomolecules is most likely helping in the stabilization of the nanoparticles outside the cell. 
As mentioned above, cation exchange reactions are one of the technologies used to generate complex nanostructures such as ternary and quaternary QDs [23,30,46,47]. The method in this case allows us to biosynthesize different NPs in three subsequent steps of the same reaction, which all have different properties. The optimization of the $\mathrm{AgNO}_{3}$ concentration added to the reaction solution was essential in the development of this protocol. By increasing the amount of $\mathrm{Ag}^{2+}$ ions, we assured that CdS NPs exchange all $\mathrm{Cd}^{2+}$ ions by obtaining Cd-free $\mathrm{Ag}_{2} \mathrm{~S}$ NPs. Based on this, the presence of a ternary structure was only achieved when the concentration of $\mathrm{Ag}^{2+}$ ions was limited by decreasing the $\mathrm{AgNO}_{3}$ concentration added to the reaction.

In recent years, $\mathrm{Ag}_{2} \mathrm{~S}$ NPs have attracted considerable attention because they are used in the synthesis of other NPs such as $\mathrm{Ag}_{2} \mathrm{~S}-\mathrm{CdS}-\mathrm{ZnS}$ and $\mathrm{AgInS}-\mathrm{Ag}_{2} \mathrm{~S}$ [48], which is due to their high biocompatibility and photoluminescent properties that makes them useful for bioimaging in deep tissues. These nanoparticles are fluorescent in the near-infrared and their emission can be tuned, depending on the nanoparticle structure and size [48]. Several protocols for the biosynthesis of silver sulfide NPs has been described with most of them involving a different process than the one described in this case since they require the incorporation of a chemical sulfur source (such as $\mathrm{Na}_{2} \mathrm{~S}$ or $\mathrm{Na}_{2} \mathrm{~S}_{2} \mathrm{O}_{3}$ ) or the sulfidation of $\mathrm{Ag}^{\mathrm{o}} \mathrm{NPs}$. Silver sulfide cellular production has been described in bacteria (Pseudomonas stutzeri and Shewanella oneidensis) and also in HepG2 mammalian cancer cells [49,50], but no reports of cation exchange protocols for obtaining these NPs has been ever published.

Regarding the biological process involved in ternary QDs biosynthesis, we have shown that E. coli is able to synthesize CdS, CdSAg, and $\operatorname{Ag}_{2} S$ NPs extracellularly when treated with different concentrations of $\mathrm{CdCl}_{2}$ and $\mathrm{AgNO}_{3}$. The presence of cysteine allows E. coli cells to metabolically produce $\mathrm{S}^{2-}$ and all the substrates required for nanocrystal biosynthesis including stabilizing agents such as cellular thiols, proteins, or peptides [45]. It is known that the use of cysteine on cell extracts or solutions stimulates the enzymatic production of sulfide that can interact with $\mathrm{Cd}^{2+}$ by generating fluorescent CdS NPs [18]. Even though CdS biosynthesis is observed with cell lysates, it is interesting that the presence of living cells is mandatory for the generation of NPs with a tunable size and physical properties through cation exchange reactions. In addition, the interaction of released biomolecules could help stabilize the nanoparticles outside the cell.

These "still unknown" biomolecules can control growth, polydispersity, and optoelectronic properties, among other parameters. In addition, biomolecules composing the QDs could help to decrease their toxicity in cell lines and bacteria, which has been described before [51]. In this context, no effect on bacterial growth was observed with the three NPs even at high concentrations $(500 \mu \mathrm{g} / \mathrm{mL})$ (Figure S2). This result is somehow surprising considering that QDs are composed by toxic elements like $\mathrm{Cd}$ and $\mathrm{Ag}$, and also a significant effect on bacterial growth curves has been previously reported in E. coli cultures exposed to $500 \mu \mathrm{g} / \mathrm{mL}$ Cd-QD synthesized by chemical methods [51]. In human cells, we observed that CdSAg QDs does not affect viability at $50 \mu \mathrm{g} / \mathrm{mL}$ but generate a significant cell death at $100 \mu \mathrm{g} / \mathrm{mL}$. In a previous report, working with a different kind of Cd-based QDs produced chemically, a $10 \%$ to $20 \%$ cell death after exposure to 50 or $100 \mu \mathrm{g} / \mathrm{mL}$ CdTe QDs was observed [43]. Toxicity could be associated with intracellular release of $\mathrm{Cd}^{+2}$ and/or $\mathrm{Ag}^{+}$, or the production of reactive oxygen species, which has been reported with other QDs [33]. However, it is important to mention that, currently, there are no studies reporting the toxicity of CdSAg QDs.

Ternary CdSAg QDs described in this case represent an intermediate structure between the seeds of CdS and the formation of $\mathrm{Ag}_{2} \mathrm{~S}$. CdSAg QDs biosynthesized by this method present higher quantum yield (QY) than CdS QDs, with 36.13\% and 20.3\%, respectively. In general, chemically synthesized nanostructures with QY values between 5\%-25\% for binary QDs and up to $80 \%$ for quaternary structures have been reported [45,47]. This is the highest QY value reported for biosynthesized nanomaterials, which is a property that favors the potential applications of these nanoparticles, particularly considering that biologically-obtained CdSAg hetero-structures have not been described to date.

The novel properties of biosynthesized ternary QDs such as near IR emission and high QY makes them excellent candidates for bioimaging and photovoltaic applications. Based on this, we tested 
CdSAg QDs as fluorescent labels on eukaryotic cells. As shown in Figure 7, HeLa cells are able to incorporate the ternary QDs when incubated in the presence of the transfecting agent PEI. The incorporation into the cells is not associated with changes in the cell morphology and the fluorescence is stable, which confirms the potential of ternary QDs as intracellular markers.

In addition, solar cells were assembled using each biosynthesized NP as sensitizer and photovoltaic parameters were determined. As expected, ternary QDs sensitized solar cells showed higher photovoltaic parameters than those obtained with binary structured NPs (Table 1). When chemically produced Cd-QDs were used as sensitizers in our solar cell system, similar photovoltaic parameters than those observed with biosynthesized CdSAg QDs were determined ( $\mathrm{V}_{\mathrm{OC}} 302 \mathrm{v} / \mathrm{s} 279 \mathrm{mV}$, ISC 0.146 $\mathrm{v} / \mathrm{s} 0.169 \mathrm{~mA} \mathrm{~cm}^{-2}$, and efficiencies of $0.0204 \% \mathrm{v} / \mathrm{s} 0.0222 \%$, respectively). Lower values were obtained with biosynthesized $\mathrm{CdS}$ and $\mathrm{Ag}_{2} \mathrm{~S}$ with 10 times the decrease in efficiency. To the best of our knowledge, there are two previous works in which the use of biologically produced QDs were tested as sensitizers in solar cells [22,52]. PbS NPs produced by an engineered strain of Stenotrophomonas maltophilia with a similar cysteine-mediated process than the one described in this study were used as sensitizers in QDSSCs. Authors determined some photovoltaic parameters of solar cells obtaining Voc values $(0.43 \mathrm{~V})$ that are consistent with those reported for solar cells sensitized with chemically-produced $\mathrm{Pb}-\mathrm{QDs}$ [52]. In addition, we recently reported the biosynthesis of CdS/CdSe Core/Shell and their application in QDSSCs. Reported photovoltaic parameters are consistent with those presented in this scenario in terms of Voc and efficiencies. Interestingly, biosynthesized ternary CdSAg QDs display the same efficiency than Core/Shell QDs produced by E. coli (0.022\%) [22].

The use of Ag NPs produced by plant extracts to improve the efficiency of solar cells has been recently published [53]. In particular, Ag NPs have been incorporated to CdS-based QDSSCs to improve their efficiency [54] by obtaining similar photovoltaic parameters to those reported in this case with efficiencies of $0.057 \%$ and $0.15 \%$ for CdS and CdSAg QDs, respectively.

The advantage of using CdSAg hetero-structures as sensitizers on QDSSCs was recently reported [55]. Solar cells based on chemically synthesized CdSAg presented higher photovoltaic parameters than those constructed using $\mathrm{TIO}_{2}, \mathrm{CdS}$, or $\mathrm{Ag}_{2} \mathrm{~S}$ [55]. This result is in agreement with the photovoltaic parameters determined in cells constructed with the NPs produced by our biological method. In addition, biologically produced QDs display similar $V_{O C}$ values than those reported with chemically-synthesized QDs (2.3-2.7 mV) [55]. The better performance of these kind of heterostructures have been associated with its capacity to decrease/suppress the electron-hole pair recombination, the utilization of a wider section of the solar spectrum (increasing the photon absorption), and a better energy level alignment $[55,56]$.

The application of QDs in photovoltaic technologies has been hindered by the costs and the environmental impact of synthesis methods. Considering the simplicity of our green method and the possibility to control the properties of the nanomaterials produced, the presented results confirm the potential of using cells as bio-factories to produce nanomaterials required by the industry.

Our results will strongly contribute to the generation of new protocols to biosynthesize cadmium semiconductor nanoparticles using microorganisms as well as for the biosynthesis of more complex QDs such as binary (e.g., CdTe, CdSe, and $\mathrm{Ag}_{2} \mathrm{~S}$ ), ternary (e.g., $\mathrm{CdSAg}$, $\mathrm{CdHgTe}$ ), and doped nanoparticles (e.g., Mn-doped CdS). Future direction of this work is to test the ability of different nanoparticle seeds to produce complex nano-heterostructures of elements like $\mathrm{Cu}, \mathrm{Se}, \mathrm{Pb}, \mathrm{Te}$, and $\mathrm{In}$, as they can be used for new applications and technologies including optical communication systems (as IR and UV-VIS light emitting materials), energy conversion (solar cells), or bioimaging (as fluorescent labels).

Supplementary Materials: The following are available online at http://www.mdpi.com/2076-2607/8/5/631/s1. Supplementary Figure S1. FTIR spectra of biosynthesized nanoparticles: (a) CdS, (b) CdSAg, and (c) $\mathrm{Ag}_{2} \mathrm{~S}$. Supplementary Figure S2. Effect of different concentrations of biosynthesized QDs on E. coli growth curves. Supplementary Figure S3. Effect of different concentrations of CdSAg QDs on the viability of AGS45 cells (MTS assay). Supplementary Figure S4. Current- voltage curves for solar cells constructed with biosynthesized CdS, $\mathrm{CdSAg}$, and $\mathrm{Ag}_{2} \mathrm{~S}$ NPs as a photosensitizer. 
Author Contributions: N.Ó-A., D.B., P.N.P., and J.M.P.-D. conceived and designed the study. N.Ó.-A., G.A.-O., J.P.M., N.Ó.-A., A.T., D.T.-A., R.S.-R., and J.M.P.-D. performed the experiments and analyzed data. D.T.-A. and R.S.-R. performed the bioimaging experiments. J.M. and A.T. developed the T.E.M. studies. A.T., J.P.M., and N.Ó.-A. performed the XRD and FT-IR experiments. G.A.-O. and N.O.-A. performed the photovoltaic characterizations. N.Ó.-A., G.A.-O., P.N.P., D.B., and J.M.P.-D. wrote the paper. All authors contributed to the scientific discussion and revision of the manuscript. All authors have read and agreed to the published version of the manuscript.

Funding: The South American Office of Aerospace and Development (SOARD) (PP), Fondecyt 1151255 (J.M.P.-D., D.B.), and INACH RT-25_16 (J.M.P.-D., D.B.) supported this work. A doctoral Fellowship from CONICYT is also acknowledged (J.M.).

Acknowledgments: This work was supported by Erika Elcira Donoso Lopez.

Conflicts of Interest: The authors declare no conflict of interest.

\section{References}

1. Kumar, A.; Siavash, S. Metallic Nanoparticles: Green Synthesis and Spectroscopic Characterization. Environ. Chem. Lett. 2017, 15, 223-231. [CrossRef]

2. Šafar, M.; Raška, I.; Shor, L.M.; Schröfel, A.; Kratošová, G.; Šafar, I. Applications of Biosynthesized Metallic Nanoparticles-A Review. Acta Biomater. 2014, 10, 4023-4042. [CrossRef]

3. Hulkoti, N.I.; Taranath, T.C. Colloids and Surfaces B: Biointerfaces Biosynthesis of Nanoparticles Using Microbes-A Review. Colloids Surf. B Biointerfaces 2014, 121, 474-483. [CrossRef] [PubMed]

4. Husseiny, M.I.; El-aziz, M.A.; Badr, Y.; Mahmoud, M.A. Biosynthesis of Gold Nanoparticles Using Pseudomonas Aeruginosa. ScienceDirect 2007, 67, 1003-1006. [CrossRef]

5. Klaus, T.; Joerger, R.; Olsson, E. Silver-Based Crystalline Nanoparticles, Microbially Fabricated. Proc. Natl. Acad. Sci. USA 1999, 96, 13611-13614. [CrossRef] [PubMed]

6. Birla, S.S.; Tiwari, V.V.; Gade, A.K.; Ingle, A.P.; Yadav, A.P.; Rai, M.K. Fabrication of Silver Nanoparticles by Phoma Glomerata and Its Combined Effect against Escherichia Coli, Pseudomonas Aeruginosa and Staphylococcus Aureus. Lett. Appl. Microbiol. 2009, 48, 173-179. [CrossRef] [PubMed]

7. Prasad, P.N. Nanophotonics; John Wiley \& Sons, Inc.: Hoboken, NJ, USA, 2004.

8. Park, T.J.; Lee, S.Y.; Heo, N.S.; Seo, T.S. In Vivo Synthesis of Diverse Metal Nanoparticles by Recombinant Escherichia Coli **. Angew. Chem. Int. Ed. 2010, 7019-7024. [CrossRef]

9. Kang, S.H.; Bozhilov, K.N.; Myung, N.V.; Mulchandani, A.; Chen, W. Microbial Synthesis of CdS Nanocrystals in Genetically Engineered E. Coli. Angew. Chem. Int. Ed. 2008, 47, 5186-5189. [CrossRef]

10. Gallardo Benavente, C.; Carrion, O.; Todd, J.; Pieretti, J.; Seabra, A.; Duran, N.; Rubilar, O.; Pérez-Donoso, J.M.; Quiroz, A. Biosynthesis of CdS Quantum Dots Mediated by Volatile Sulfur Compounds Released by Antarctic Pseudomonas Fragi. Front. Microbiol. 2019, 10, 1866. [CrossRef]

11. Monras, J.P.; Diaz, V.; Bravo, D.; Montes, R.A.; Chasteen, T.G.; Osorio-Roman, I.O.; Vasquez, C.C.; Perez-Donoso, J.M. Enhanced Glutathione Content Allows the In Vivo Synthesis of Fluorescent CdTe Nanoparticles by Escherichia Coli. PLoS ONE 2012, 7, e48657. [CrossRef]

12. Warren, Y.A.; Citron, D.M.; Merriam, C.V.; Goldstein, E.J.C.; Icrobiol, J.C.L.I.N.M. Biochemical Differentiation and Comparison of Desulfovibrio Species and Other Phenotypically Similar Genera. J. Clin. Microbiol. 2005, 43, 4041-4045. [CrossRef] [PubMed]

13. Bang, S.; Clark, D.S.; Keasling, J.A.Y.D. Engineering Hydrogen Sulfide Production and Cadmium Removal by Expression of the Thiosulfate Reductase Gene (PhsABC) from Salmonella Enterica Serovar Typhimurium in Escherichia Coli. Appl. Envion. Microbiol. 2000, 66, 3939-3944. [CrossRef] [PubMed]

14. Gallardo, C.; Monras, J.P.; Plaza, D.O.; Collao, B.; Saona, L.A.; Duran-Toro, V.; Venegas, F.A.; Soto, C.; Ulloa, G.; Vasquez, C.C.; et al. Low-Temperature Biosynthesis of Fluorescent Semiconductor Nanoparticles (CdS) by Oxidative Stress Resistant Antarctic Bacteria. J. Biotechnol. 2014, 187, 108-115. [CrossRef] [PubMed]

15. Plaza, D.O.; Gallardo, C.; Straub, Y.D.; Bravo, D.; Pérez-Donoso, J.M. Biological Synthesis of Fluorescent Nanoparticles by Cadmium and Tellurite Resistant Antarctic Bacteria: Exploring Novel Natural Nanofactories. Microb. Cell Fact. 2016, 15. [CrossRef]

16. Awano, N.; Wada, M.; Mori, H.; Nakamori, S. Identification and Functional Analysis of Escherichia Coli Cysteine Desulfhydrases. Appl. Envion. Microbiol. 2005, 71, 4149-4152. [CrossRef] 
17. Marusak, K.E.; Feng, Y.; Eben, C.F.; Payne, S.T.; Cao, Y.; You, L.; Zauscher, S. Cadmium Sulphide Quantum Dots with Tunable Electronic Properties by Bacterial Precipitation. RSC Adv. 2016, 6, 76158-76166. [CrossRef]

18. Dunleavy, R.; Lu, L.; Kiely, C.J.; McIntosh, S.; Berger, B.W. Single-Enzyme Biomineralization of Cadmium Sulfide Nanocrystals with Controlled Optical Properties. Proc. Natl. Acad. Sci. USA 2016, 113, 5275-5280. [CrossRef]

19. Venegas, F.A.; Saona, L.A.; Monrás, J.P.; Órdenes-Aenishanslins, N.; Giordana, M.F.; Ulloa, G.; Collao, B.; Bravo, D.; Pérez-Donoso, J.M. Biological Phosphorylated Molecules Participate in the Biomimetic and Biological Synthesis of Cadmium Sulphide Quantum Dots by Promoting H 2 S Release from Cellular Thiols. RSC Adv. 2017, 7, 40270-40278. [CrossRef]

20. Ulloa, G.; Collao, B.; Araneda, M.; Escobar, B.; Álvarez, S.; Bravo, D.; Pérez-Donoso, J.M. Use of Acidophilic Bacteria of the Genus Acidithiobacillus to Biosynthesize CdS Fluorescent Nanoparticles (Quantum Dots) with High Tolerance to Acidic PH. Enzyme Microb. Technol. 2016, 95, 217-224. [CrossRef]

21. Bruna, N.; Collao, B.; Tello, A.; Caravantes, P.; Monrás, J.P. Synthesis of Salt-Stable Fluorescent Nanoparticles (Quantum Dots) by Polyextremophile Halophilic Bacteria. Sci. Rep. 2019, 9, 1-13. [CrossRef]

22. Órdenes-Aenishanslins, N.; Anziani-Ostuni, G.; Quezada, C.P.; Espinoza-González, R.; Bravo, D.; Pérez-Donoso, J.M. Biological Synthesis of CdS/CdSe Core/Shell Nanoparticles and Its Application in Quantum Dot Sensitized Solar Cells. Front. Microbiol. 2019, 10. [CrossRef] [PubMed]

23. Tsolekile, N.; Parani, S.; Matoetoe, M.C. Nano-Structures \& Nano-Objects Evolution of Ternary I - III - VI QDs: Synthesis, Characterization and Application. Nano Struct. Nano Objects 2017, 12, 46-56. [CrossRef]

24. Saravanan, K.; Suriakarthick, R.; Ananthakumar, S.; Babu, S.M.; Selladurai, S. Colloidal Synthesis of Copper Cadmium Sulphide (CuCdS2) Nanoparticles and Its Structural, Optical and Morphological Properties. Mater. Sci. Semicond. Process. 2017, 66, 123-130. [CrossRef]

25. Robinson, R.D.; Sadtler, B.; Demchenko, D.O.; Erdonmez, C.K.; Wang, L.-W.; Alivisatos, A.P. Spontaneous Superlattice Formation in Nanorods Through Partial Cation Exchange. Science 2013, 355. [CrossRef] [PubMed]

26. Santra, P.K.; Kamat, P.V. Mn-Doped Quantum Dot Sensitized Solar Cells: A Strategy to Boost Efficiency over 5\%. J. Am. Chem. Soc. 2012, 23-26. [CrossRef]

27. Chen, W.; Zhang, J.Z.; Joly, A.G. Optical Properties and Potential Applications of Doped Semiconductor Nanoparticles. J. Nanosci. Nanotechnol. 2004, 4, 919-947. [CrossRef]

28. Ren, F.; Zhao, H.; Vetrone, F.; Ma, D. Microwave-Assisted Cation Exchange toward Synthesis of near-Infrared Emitting PbS/CdS Core/Shell Quantum Dots with Significantly Improved Quantum Yields through a Uniform Growth Path. Nanoscale 2013, 7800-7804. [CrossRef]

29. Lai, P.; Huang, C.; Chou, T.; Ou, K.; Chang, J. Aqueous Synthesis of Ag and Mn Co-Doped In 2 S 3/ZnS Quantum Dots with Tunable Emission for Dual-Modal Targeted Imaging. Acta Biomater. 2016, 50, 522-533. [CrossRef]

30. Rivesta, J.B.; Jain, P.K. Cation Exchange on the Nanoscale: An Emerging Technique for New Material Synthesis, Device Fabrication, and Chemical Sensing. Chem. Soc. Rev. 2013, 89-96. [CrossRef]

31. Beberwyck, B.J.; Surendranath, Y.; Alivisatos, A.P. Cation Exchange: A Versatile Tool for Nanomaterials Synthesis. J. Phys. Chem. 2013, 117, 19759-19770. [CrossRef]

32. Luther, J.M.; Zheng, H.; Sadtler, B.; Alivisatos, A.P. Synthesis of PbS Nanorods and Other Ionic Nanocrystals of Complex Morphology by Sequential Cation Exchange Reactions. J. Am. Chem. Soc. 2009, 131, 16851-16857. [CrossRef] [PubMed]

33. Hu, L.; Zhang, C.; Zeng, G.; Chen, G.; Wan, J.; Guo, Z.; Wu, H.; Yu, Z.; Liu, J. Metal-Based Quantum Dots: Synthesis, Surface Modification, Transport and Fate in Aquatic Environments and Toxicity to Microorganisms. RSC Adv. 2016, 6, 78595-78610. [CrossRef]

34. Órdenes-Aenishanslins, N.; Anziani-Ostuni, G.; Vargas-Reyes, M.; Alarcón, J.; Tello, A.; Pérez-Donoso, J.M. Pigments from UV-Resistant Antarctic Bacteria as Photosensitizers in Dye Sensitized Solar Cells. J. Photochem. Photobiol. B Biol. 2016, 162, 707-714. [CrossRef] [PubMed]

35. Yang, F.; Yan, N.; Huang, S.; Sun, Q.; Zhang, L.; Yu, Y. Zn-Doped CdS Nanoarchitectures Prepared by Hydrothermal Synthesis: Mechanism for Enhanced Photocatalytic Activity and Stability under Visible Light. J. Phys. Chem. C 2012, 116, 9078-9084. [CrossRef] 
36. Yousefi, M.H.; Abdolhosseinzadeh, A.A.; Fallah,H.R.; Optics, Q.; Khosravi, A.A. Growth and Characterization of CdS and CdS:Ag Luminescent Quantum Dots Dispersed in Solution. Mod. Phys. Lett. B 2010, 24, 2591-2599. [CrossRef]

37. Je, K.; Ju, H.; Treguer, M.; Cardinal, T.; Park, S. Local Field-Induced Optical Properties of Ag-Coated CdS Quantum Dots. Opt. Soc. Am. 2006, 14, 7994-8000. [CrossRef]

38. Tello, A.; Gómez, H.; Muñoz, E.; Riveros, G.; Pereyra, C.J.; Dalchiele, E.A. Electrodeposition of Nanostructured ZnO Thin Films from Dimethylsulfoxide Solution: Effect of Temperatures on the Morphological and Optical Properties. J. Electrochem. Soc. 2012, 159, 750-755. [CrossRef]

39. Manikandan, K.; Surendra Dilip, C.; Mani, P.; Prince, J. Deposition and Characterization of CdS Nano Thin Film with Complexing Agent Triethanolamine. Am. J. Eng. Appl. Sci. 2015, 8, 3-318. [CrossRef]

40. Kelly, D.; Singh, A.; Barrett, C.A.; O’Sullivan, C.; Coughlan, C.; Laffir, F.R.; O’Dwyer, C.; Ryan, K.M. A facile spin-cast route for cation exchange of multilayer perpendicularly-aligned nanorod assemblies. Nanoscale 2011, 3, 4580-4583. [CrossRef]

41. Órdenes-Aenishanslins, N.; Saona, L.; Durán-Toro, V.; Monrás, J.; Bravo, D.; Pérez-Donoso, J. Use of Titanium Dioxide Nanoparticles Biosynthesized by Bacillus Mycoides in Quantum Dot Sensitized Solar Cells. Microb. Cell Fact. 2014, 13, 90. [CrossRef]

42. Piacenza, E.; Presentato, A.; Turner, R.J. Stability of Biogenic Metal(Loid) Nanomaterials Related to the Colloidal Stabilization Theory of Chemical Nanostructures. Crit. Rev. Biotechnol. 2018, 38, 1137-1156. [CrossRef] [PubMed]

43. Pérez-Donoso, J.M.; Monrás, J.P.; Bravo, D.; Aguirre, A.; Quest, A.F.; Osorio-Román, I.O.; Aroca, R.F.; Chasteen, T.G.; Vásquez, C.C. Biomimetic, Mild Chemical Synthesis of Cdte-GSH Quantum Dots with Improved Biocompatibility. PLoS ONE 2012, 7. [CrossRef] [PubMed]

44. Bao, H.; Hao, N.; Yang, Y.; Zhao, D. Biosynthesis of Biocompatible Cadmium Telluride Quantum Dots Using Yeast Cells. Nano Res. 2010, 481-489. [CrossRef]

45. Ulloa, G.; Quezada, C.P.; Araneda, M.; Escobar, B.; Fuentes, E.; álvarez, S.A.; Castro, M.; Bruna, N.; Espinoza-González, R.; Bravo, D.; et al. Phosphate Favors the Biosynthesis of CdS Quantum Dots in Acidithiobacillus Thiooxidans ATCC 19703 by Improving Metal Uptake and Tolerance. Front. Microbiol. 2018, 9, 234. [CrossRef] [PubMed]

46. De Trizio, L.; Prato, M.; Genovese, A.; Casu, A.; Povia, M.; Simonutti, R.; Alcocer, M.J.P.; Andrea, C.D.; Tassone, F.; Manna, L. Strongly Fluorescent Quaternary Cu - In - Zn - S Nanocrystals Prepared from Cu 1 x InS 2 Nanocrystals by Partial Cation Exchange. Chem. Mater. 2012, 24, 2400-2406. [CrossRef]

47. Zhou, Z.; Yang, L.; Yan, R.; Zhao, J.; Liu, Y.; Lai, L.; Jiang, F.; Maskow, T.; Liu, Y. Mn-Doped ZnSe Quantum Dots Initiated Mild and Rapid Cation Exchange for Tailoring the Composition and Optical Properties of Colloid Nanocrystals: Novel Template, New Applications. Nanoscale 2017, 9, 2824-2835. [CrossRef]

48. Bailey, R.E.; Nie, S. Alloyed Semiconductor Quantum Dots: Tuning the Optical Properties without Changing the Particle Size. J. Am. Chem. Soc. 2003, 125, 7100-7106. [CrossRef]

49. Doh, H.; Hwang, S.; Kim, S. Size-Tunable Synthesis of Nearly Monodisperse Ag 2 S Nanoparticles and Size-Dependent Fate of the Crystal Structures upon Cation Exchange to AgInS 2 Nanoparticles. Chem. Mater. 2016, 8123-8127. [CrossRef]

50. Ashrafi, S.J.; Rastegar, M.F.; Ashrafi, M.; Yazdian, F.; Pourrahim, R.; Suresh, A.K. Influence of External Factors on the Production and Morphology of Biogenic Silver Nanocrystallites. J. Nanosci. Nanotechnol. 2013, 13, 2295-2301. [CrossRef]

51. Díaz, V.; Ramírez-Maureira, M.; Monrás, J.P.; Vargas, J.; Bravo, D.; Osorio-Román, I.O.; Vásquez, C.C.; Pérez-Donoso, J.M. Spectroscopic Properties and Biocompatibility Studies of CdTe Quantum Dots Capped with Biological Thiols. Sci. Adv. Mater. 2012, 4, 609-616. [CrossRef]

52. Spangler, L.C.; Lu, L.; Kiely, C.J.; Berger, B.W.; McIntosh, S. Biomineralization of PbS and PbS-CdS Core-Shell Nanocrystals and Their Application in Quantum Dot Sensitized Solar Cells. J. Mater. Chem. 2016, 4, 6107-6115. [CrossRef]

53. Saravanan, S.; Kato, R.; Balamurugan, M.; Kaushik, S.; Soga, T. Efficiency Improvement in Dye Sensitized Solar Cells by the Plasmonic Effect of Green Synthesized Silver Nanoparticles. J. Sci. Adv. Mater. Devices 2017, 2, 418-424. [CrossRef] 
54. Prasad, M.B.R.; Deena, S.; Rajesh, C.; Pandit, V.K.; Pathan, H.M.; Prasad, M.B.R.; Deena, S.; Rajesh, C.; Pandit, V.K. Employing Green Synthesized Silver Nanoparticles as Light Harvesters in Nanostructured Solar Cells. J. Renew. Sustain. Energy 2013, 5, 031615. [CrossRef]

55. Pawar, S.A.; Patil, D.S.; Hyeok, J.; Patil, P.S.; Cheol, J. Quantum Dot Sensitized Solar Cell Based on TiO2/CdS/Ag2S Heterostructure. Opt. Mater. 2017, 66, 644-650. [CrossRef]

56. Xu, X.; Wang, X.; Zhang, Y.; Li, P. Ion-Exchange Synthesis and Improved Photovoltaic Performance of CdS/Ag2S Heterostructures for Inorganic-Organic Hybrid Solar Cells. Solid State Sci. 2016, 61, 195-200. [CrossRef]

(C) 2020 by the authors. Licensee MDPI, Basel, Switzerland. This article is an open access article distributed under the terms and conditions of the Creative Commons Attribution (CC BY) license (http://creativecommons.org/licenses/by/4.0/). 